\title{
USEFUL OF TOKYO GUIDELINES IN THE DIAGNOSIS OF ACUTE CHOLECYSTITIS. ANATOMO- PATHOLOGIE CORRELATIONSHIP
}

UTILIDAD DE LAS GUIAS DE TOKIO EN LA COLECISTITIS AGUDA. CORRELACIÓN ANATOMOPATOLÓGICA

\author{
Christian Janikow*, Edgardo Corti**, Nicolás Menso**, Gastón Moretti**, Martín Alé*, \\ Martín Sanchez*, Paul Lada***.
}

\begin{abstract}
Background: In the year 2007 a group of experts come together to discuss criteria for acute cholecystitis and to establish therapeutic guidelines and states of gravity in this disease.

Objectives: we correlated the criteria of the Tokyo Guidelines 2007 with the anatomopathology study of the surgical specimen.

Setting: Service of Urgencies of the National Clinic Hospital in Córdoba, Argentine.

Methods: We studied 324 patients (120 male and 204 female) older than 15 years and without limits of age with the criteria of acute cholecystitis a cord to the Tokyo guidelines 2007. 202 patients had a preoperative diagnosis of chronic cholecystitis and 89 of acute cholecystitis, all received cholecystectomy and studied the operative specimen in the anatomopathology department. Anatomopathology criteria for acute cholecystitis were the presence of polimorpho nuclear cells (PMN), for acute exacerbation of chronic cholecystitis the presence of PMN and monomorpho nuclear cells (MN), and for chronic cholecystitis the presence of MN with or without fibrosis.

Results: This work showed $82,14 \%$ of sensitivity for the diagnostic criteria of Tokyo guidelines, $74,03 \%$ of specificity, and positive predictive value of $46 \%$. With the Bayes Theorem the predictive value in Córdoba city was $18,49 \%$.

Conclusion: There is an important difference in the specificity and positive predictive value between our work and the Tokyo guidelines for acute cholecystitis. There is an important group of patients in our work with acute exacerbation of chronic cholecystitis that is not classified in the diagnostic criteria for acute cholecystitis of Tokyo guidelines.
\end{abstract}

Keywords: Tokyo guidelines 2007, acute cholecystitis, chronic cholecystitis, acute exacerbation of chronic cholecystitis, pathology study of the specimen.

\footnotetext{
* Surgeon of Urgencies. National Clinic Hospital. Faculty of Medicine. University National of Córdoba. Argentine.

** Residents of Urgencies. National Clinic Hospital. Faculty of Medicine. University National of Córdoba. Argentine.

*** Chef of Service of Urgencies. National Clinic Hospital. Faculty of Medicine. University National of Córdoba. Argentine.

*** Paul Eduardo Lada

Crisol 167. $3^{\circ}$. M. Nueva Córdoba.

(5000) Córdoba.

ARGENTINA
} 


\section{RESUMEN}

Introducción: En el año 2007 un grupo de expertos reunidos en Tokio han ideado los criterios para el diagnóstico de colecistitis aguda con el objeto de establecer pautas terapéuticas e idear grados de gravedad en esta patología.

Material y Método: Se estudiaron 324 pacientes (120 masculinos y 204 femeninos) mayores de 15 años sin límite de edad con los criterios diagnósticos para colecistitis aguda según las guías de Tokio 2007. Se diferenciaron 202 pacientes con diagnóstico preoperatorio de colecistitis crónica litiásica y 89 con diagnóstico de colecistitis aguda, todos sometidos a colecistectomía y a posterior se estudiaron las piezas operatorias en el departamento de anatomía patológica utilizando como criterios de colecistitis aguda la presencia de células polimorfo nucleares (PMN), de colecistitis crónica reagudizada la presencia de PMN mas mononucleares ( $\mathrm{MN}$ ), y para colecistitis crónica la presencia de $\mathrm{MN}$ con o sin focos de fibrosis.

Resultados: El estudio mostró una sensibilidad del 82,14\% para los criterios diagnósticos de las guías de Tokio, una especificidad del $74,03 \%$ y un valor predictivo positivo del $46 \%$. Aplicando el Teorema de Bayes para analizar el valor predictivo, se obtuvo que el mismo sea del $18,49 \%$ en nuestra comunidad. Conclusiones: Existe una notoria diferencia en cuanto a la especificidad y valor predictivo positivo de los criterios de diagnóstico de CA establecidos en las guías de Tokio y las obtenidas en nuestro trabajo. Existe un grupo importante de pacientes con diagnóstico de enfermedad crónica reagudizada que no es clasificada en los trabajos de Tokio.

Palabras claves: Guías de Tokio 2007. Colecistitis Aguda. Colecistitis Crónica. Exacerbación aguda de la colecistitis crónica. Estudio de las piezas quirúrgicas.

\section{Introduction}

In the year 2007 a group of experts established in Tokyo criteria for the diagnosis of acute Cholecystitis aiming therapeutic guidelines and severity grading ${ }^{(1)}$ and in 2013 they made an update. They agreed that's enough for the suspected diagnosis of acute Cholecystitis one local plus one systemic inflammation sign, and for the definite diagnosis imaging findings as support ${ }^{(1)}$. True is that the diagnostic capacity of this guideline is very high but acute hepatitis, other acute abdominal diseases, and chronic cholecystitis should be excluded (1).

\section{Methods and Materials}

We studied 324 patients, 120 male and 204 female, older than 15 years without limit of age that received cholecystectomy by any procedure. This study began in the year 2008 with a protocol for acute Cholecystitis based on the Tokyo guidelines 2007 (fig 1). 324 patients were rated with the Tokyo guidelines (TG) for acute cholecystitis, 33 were excluded because of incomplete dates for the statistical study. From the 291 patients we obtained four groups, the first with 177 chronic calculous cholecystitis (CCC), 28 of them had a history of sporadic colic pain, all of them received surgical treatment. The second group had 89 patients with a diagnosis of acute cholecystitis (AC) and they were rated in to stage I, II or III as TG indicates, two of them were acalculous acute cholecystitis (AAC), all of them received urgent cholecystectomy in the first 72 hours ${ }^{(3)}$.

The third group had 18 patients with choledochal syndrome without cholangitis, they also received urgent surgery. The fourth group had 7 patients with a diagnosis of acute pancreatitis (AP) and they received surgery during their stay with the diagnosis of AP and CCC (fig 2). So the group 
A. Local signs of inflammation etc.

(1) Murphy's sign, (2) RUQ mass/pain/tenderness

$B$. Systemic signs of inflammation etc.

(1) Fever, (2) elevated CRP, (3) elevated WBC count

C. Imaging findings

Imaging findings characteristic of acute cholecystitis. Suspected diagnosis: One item in $A+$ one item in $B$ Definite diagnosis: One item in $A+$ one item in $B+C$ Acute hepatitis, other acute abdominal diseases, and chronic cholecystitis should be excluded.

RUQ: right upper abdominal quadrant, CRP: C-reactive protein, WBC: white blood cell

Figure 1: Diagnostic criteria for acute cholecystitis

of CCC were in total 202 patients, and the group of $A C$ was 89 . We studied the surgical specimen in the department of pathology. The criteria acute for inflammatory process where the presence of polymorph nuclear cells (PMN), for acute exacerbation of chronic cholecystitis the presence of PMN and monomorphic nuclear cells (MN), and for chronic cholecystitis the presence of MN with or without fibrosis.

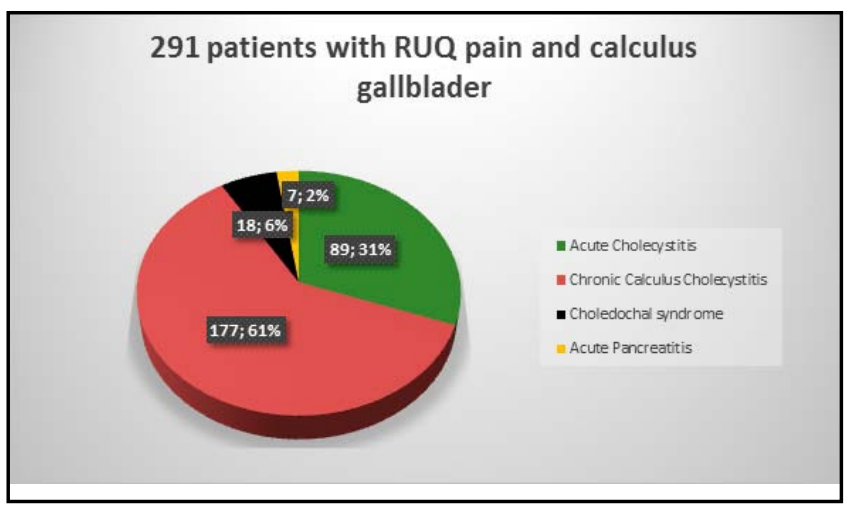

Figure 2: Patient's Group

\section{Results}

All the samples were studied macroscopically and microscopically in the department of pathology. The pathological anatomy diagnosis was sorted out in acute cholecystitis, calculus chronic cholecystitis and exacerbation in calculus chronic cholecystitis based on the presence or absence of polymorph nuclear and monomorphonuclear cells ${ }^{(4)}$. From the group of 87 patients with $\mathrm{AC}$ diagnostic,
23 had pathologically an AC has diagnosis and 27 of a CCC, the 39 patients left had an exacerbation in calculus chronic cholecystitis. From the group of 202 patients with CCC, 5 had AC has pathologically diagnosis, 77 had CCC and 102 had an exacerbation in calculus chronic cholecystitis (Table 1).

The study showed a sensitivity of $82,14 \%$ of diagnostic using Tokyo guidelines and a specificity of $74.03 \%$ and a positive predictive value of $46 \%$. Knowing that the prevalence of calculous biliary disease in the province of Córdoba is $28,8 \%{ }^{(5)}$ and using Bayes theorem we find out that the predictive value is $18,49 \%{ }^{(6)}$.

\section{Discussion}

The following work, that begun in 2008 in the Service of Urgencies the National Clinic Hospital of Córdoba Argentine is a foretaste of a long process of study of patients operated for acute cholecystitis and gallstones in the context of chronic cholelithiasis. We try to present the relationship between the diagnostic criteria of Tokyo guidelines 2007 that were not modified in its 2013 update (2), with physiological examination of surgical specimens from these patients. In the same study, in later works, we will try to explain the discrepancies found in the comparison, we found a big number of patients with an exacerbation in calculus chronic cholecystitis as physiological diagnosis in the group of patients who were operated by none criteria for $\mathrm{AC}$ according Tokyo guidelines.

Based on two major diagnostic groups, the first one is the preoperative diagnosis that includes patient's clinical and complementary studies as set out in the guidelines for Tokyo 2007, and the second diagnostic group is represented by the pathological study of the surgical piece. Comparison was established between them and calculated the sensitivity, specificity and positive predictive value of a positive test that in this case is represented by the diagnostic criteria Tokyo guidelines. Tokyo guidelines proposed that elevated C-reactive protein with a positive acute cholecystitis ultrasound has a sensitivity of $97 \%$ and specificity of $76 \%$ and a positive predictive value of $95 \%$ (1). 


\begin{tabular}{|cc|c|c|c|}
\hline TG diagnostic & Total Patients & $\begin{array}{c}\text { Pathologically } \\
\text { Acute } \\
\text { Cholecystitis }\end{array}$ & $\begin{array}{c}\text { Pathologically } \\
\text { Chronic Calculus } \\
\text { Cholecystitis }\end{array}$ & $\begin{array}{c}\text { Pathologically } \\
\text { Exacerbation in } \\
\text { Calculus Chronic } \\
\text { Cholecystits }\end{array}$ \\
$\begin{array}{c}\text { Acute } \\
\text { Cholecystitis } \\
\text { Chorinc Calculus } \\
\text { Cholecystitis }\end{array}$ & $\mathbf{8 7}$ & 23 & 27 & 39 \\
\hline
\end{tabular}

Table 1: Results of the pathological gallbladder study

The proposed diagnostic criteria cover three topics, signs of local pain and inflammation, signs of systemic inflammation and especially ultrasound imaging signals. With the presence of a sign of local inflammation and a systemic inflammation can be sufficient for diagnosis of acute cholecystitis, but coupled with imaging signs could confirm it.

The paper clarifies that should be excluded chronic cholecystitis, hepatitis and other causes of abdominal pain (1). The guidelines do not check the preoperative diagnosis with a pathological examination of the surgical specimen. It is thus that arises from our concern and experience a question that made us reflect on the accuracy of our preoperative diagnosis because a high percentage of cases does not match the intraoperative finding. To try to eliminate subjectivity we decided not to compare the preoperative with the intraoperative diagnosis, instead with the study of surgical specimens. We were surprised by the initial results; there are a lot of patients operated as chronic cholecystitis who actually had a chronically inflamed organ exacerbation, perhaps being coincident with the difficult cholecystectomy cases in this group. These patients with chronic inflammation are operated programmatically and may become a major surgical challenge for the surgeon because of a vesicular process with chronic thickened walls, fibrous and increased consistency together with an acute inflammation that often implies an inflamed Calot triangle, adhered intestine and duodenum and sometimes attached main bile duct.
The differences in sensitivity, specificity and positive predictive value indicated a difference between diagnostic criteria for AC in Tokyo Guidelines and our study, $97 \%$ sensitivity in Tokyo Guidelines and $82 \%$ in our work, in terms of the specificity values they are similar, about $75 \%$, the biggest difference is found in the positive predictive value of $95 \%$ in Tokyo Guidelines and $46 \%$ for us. If we try to know the real predictive value we compare this with the prevalence of gallstone disease in the community where the sample was taken according to the Bayes theorem, knowing that the prevalence is $28.8 \%$ in Cordoba we obtain a predictive value of $18.49 \%$, strikingly lower. Would explain this, perhaps, the fact that our sample was taken by patients from a single institution and most of them from the General Guard Service losing those who do it as an outpatient, and then it would be a representative sample of a population of the emergency service and not from all patients with biliary stone disease.

There are now several points to clarify. Can only the presence of polymorph nuclear cells in the surgical specimen define an acute cholecystitis?, Is it enough the presence of pain, sign of systemic inflammation and the support of an image to define acute cholecystitis? This first work is purely descriptive in view of the data collected, the number of patients continues to increase and perhaps it modified with new results, however we were surprised with the first analysis obtained which forced us to make it known by the present work. The 
challenge is to continue including cases not yet analysed and raise the spectre to a representative sample of the population of patients suffering from gallstone disease and distinguish patients with acute exacerbation from chronic inflammation so they can be boxed to into a category and not keep calling it difficult cases.

Conflict of Interest: The authors declare that there is no conflict of interest regarding the publication of this paper.

\section{References}

1.- Hirota M, Takada T, Kawarada Y, et al.: J. Hepatobiliary. Pancreat. Surg. 2007. 14(1): 78-82.

2.- Yokoe M, Takada T, Strasberg SM, et al.: TG13 diagnostic criteria and severity grading of acute cholecystitis.J. Hepatobiliary. Pancreat. Sci. 2013. 20(1): 35-46.

3.- Gutt CN, Encke J, Köninger J, et al.: Acute cholecystitis: early versus delayed cholecystectomy, a multicenter randomized trial (ACDC study, NCT00447304). Ann. Surg. 2013. 258(3): 385-393. 4.- Terada T. : Histopathologic features and frequency of gall bladder lesions in consecutive 540 cholecystectomies. Int. J. Clin. Exp. Pathol. 2013. 6(1): 91-96.

5.- Serra CA, Martelotto G, Galli SB.: Frecuencia de litiasis biliar en 1500 autopsias. Rev. Argent. Cir. 1991. 61: 85-88.

6.- Guerrero R, Gonzalez C, Medina E. Epidemiología. Addison-Wesley Iberoamericana, 1986. ISBNO201-03078-0. Pag: 181-183. 